\title{
Pulmonary function tests in Egyptian schoolchildren in rural and urban areas
}

Walid Al-Qerem ${ }^{1}$ and Jonathan Ling ${ }^{2}$

${ }^{1}$ Faculty of Pharmacy, Al-Zaytoonah University of Jordan, Amman, Jordan (Correspondence to: Walid A. Al-Qerem: waleed.qirim@zuj.edu.jo). 2School of Nursing and Health Sciences, University of Sunderland, Sunderland, United Kingdom.

\begin{abstract}
Background: Previous studies have shown a negative association between urban environments and pulmonary function. Objectives: This longitudinal study examined the effect of an urban environment on pulmonary function tests of children by comparing children from an urban and a rural area in Egypt. The effect of other factors on pulmonary function, including obesity, breastfeeding and parental atopy, was also examined.
\end{abstract}

Methods: Children aged 7-12 years from rural Shibin El-Kom and urban Cairo were enrolled in the study. Forced expiratory volume in the first second (FEV1), forced vital capacity (FVC), forced expiratory rate and peak expiratory flow rate (PEFR) were measured 5 times over a period of 2 years, at 6-monthly intervals. Factorial repeated measures analysis of variance was used to evaluate the differences in the rate of change in FEV1 predicted\%, FVC predicted\% and PEFR between the children in Cairo and Shibin El-Kom. Generalized linear mixed models were used to analyse factors associated with pulmonary function test results.

Results: Generalized linear regression showed that living in Cairo decreased $\log (\mathrm{FVC}), \log (\mathrm{FEV} 1)$ and $\log (\mathrm{PEFR})$. Significant differences were found in the changes occurring between the 2 locations in the last 3 visits; children in Cairo showed a smaller increase in pulmonary function.

Conclusions: Differences in pulmonary function in the 2 locations increased significantly with time, indicating a negative effect on lung function of living in urban Cairo. The findings could be used to help in the development of policies in Egypt and other developing countries to improve respiratory health, including promoting breastfeeding and reducing outdoor air pollution.

Keywords: Pulmonary function test, rural versus urban environment, Egypt, schoolchildren, spirometry

Citation: Al-Qerem WA; Ling J. Pulmonary function tests in Egyptian schoolchildren in rural and urban areas. East Mediterr Health J. 2018;24(4):325332. https://doi.org/10.26719/2018.24.4.325

Received: 07/11/16; accepted: 22/05/17

Copyright (c) World Health Organization (WHO) 2018. Some rights reserved. This work is available under the CC BY-NC-SA 3.o IGO license (https:// creativecommons.org/licenses/by-nc-sa/3.o/igo).

\section{Introduction}

Air pollution is recognized as a risk factor for several negative health outcomes including increased mortality, increased hospital admissions for both respiratory and cardiovascular diseases, and exacerbation of asthma and chronic obstructive pulmonary disease (1). There is a negative association between long-term exposure to air pollution and lung function (2).

Urban environments can also negatively affect health. This effect can be attributed to several factors in addition to air pollution, including diet, socioeconomic status, infections, stress, allergic exposure and parasitic infections (3). Inner-city children appear to have more episodes of acute respiratory infection than those living in rural areas (3) and lung function growth rate is higher in rural children than urban children (4), although this effect could be reversible (5). Other studies have shown the protective effect of farming activities and daily contact with livestock in different parts of the world $(6,7)$, including Egypt (8).

This study evaluated the hypothesis that there are differences in children's lung function between urban and rural areas of Egypt. Air pollution in Cairo is considered one of the greatest challenges to health in Egypt because of its multiple sources, including industrial waste, burning of agricultural residues, vehicle emissions and pollutants resulting from open burning of municipal solid waste (9). The study compared respiratory function between schoolchildren in an urban area (Cairo) and a rural area (Shibin El-Kom) of Egypt and also explored the relative importance of an urban-rural setting and other known risk factors in relation to respiratory function.

\section{Methods}

\section{Study design, setting and sample}

This longitudinal study examined the effect of a rural versus urban environment and other risk factors on pulmonary function tests in schoolchildren in Egypt. Schoolchildren aged 7-12 years from 2 locations in Egypt were enrolled in the study. The first, exposed, group was drawn from the urban city of Cairo and the second, comparison, group was from the rural area of Shibin El-Kom. Cairo, the capital of Egypt, has a population of 18.772 million (10). The city is located around the Nile River and surrounded 
by large deserts. Shibin El-Kom, the provincial capital of Monofeya Governorate, is located in the Delta region 95 $\mathrm{km}$ from Cairo inner city. Shibin El-Kom is a rural town with most of its population working in farming.

The children were enrolled from 2 predominantly middle-class schools in Cairo and Shben El-Kom. Fajr AlIslam school in Shibin El-Kom and Al Husain school in the centre of Cairo. The 2 schools were similar in terms of class size and cleanliness.

According to Cohen, the number of participants required for an appropriate sample is associated with the number of factors and the expected effect size (11). He recommends 200 as sufficient when there are up to 20 predictors. We calculated that the study required a minimum sample size of 323 . This figure was based on a total target population in the schools of 2000 , with a confidence level of $95 \%$ and a $5 \%$ margin of error. Our sample size was substantially larger than the minimum as we did not want to exclude children from participating if they wished to. Therefore, all children who were eligible for inclusion (being able to perform the test successfully) in each school and who wished to participate were tested. Children who were unable to perform the spirometry successfully were excluded. In addition, from the 3rd visit, children who were exposed to smoke or had a pulmonary or heart disease were excluded. This was done because we thought to include all these variables as independent factors in the regression analysis, but this needed a bigger sample than we had, so it was decided to control these variables by adding them to the exclusion criteria. Participants from the 2 groups were matched on age and gender. This resulted in comparable age, body mass index (BMI), gender and height between the 2 locations, as the data show.

\section{Data collection}

The data presented in this study are part of a comprehensive study (12) that included circulating an Arabic version of the ISAAC questionnaires (13), and additional questions related to environmental factors. The children were given the questionnaire and the consent form to take home to be completed by their parents. The consent form included a short summary of the study and its objectives and the questionnaire comprised questions about parental smoking habits and child health status, including questions about asthma and other pulmonary diseases and medications used.

The pulmonary function tests was performed every 6 months in March and September over a period of 2 years after the first visit, therefore testing took place a total of 5 times. Forced expiratory volume in the first second (FEV1), forced vital capacity (FVC), forced expiratory rate (FEV1/FVC*100) and peak expiratory flow rate (PEFR) were measured.

A room was allocated for the spirometry test in each school. The children were divided into groups of 15. Each group entered the room consecutively where the weight and height of each child was measured. An explanation of the spirometry test was given for each group before the children performed the test. The tests were performed using a Vitalograph Micro spirometer. The same spirometer was used by the same tester for all tests and for all visits.

Before the spirometry test, each child was asked about illnesses, exposure to smoking and medication used. Spirometry tests were performed according to the guidelines of the European Respiratory Society (14). Each child was asked to take a deep breath and then blow out as strongly and as fast as they could for at least 6 seconds until complete exhalation. Nose clips were used to avoid any air leakage and disposable mouthpieces were used to preserve good hygiene conditions and prevent any spread of infection. Children were told to seal their lips around the mouthpiece before blowing out. The test was repeated 3 times and the best reading was recorded

Calibration checks were performed daily. The syringe used to check the volume calibration of spirometers had an accuracy of $\pm 15 \mathrm{~mL}$. Calibration syringes were checked for leakage by attempting to empty them with the outlet corked. Any dropped or damaged syringe were discarded. The volume accuracy of the spirometer was checked with a single discharge of a 3-litre calibrated syringe.

Manoeuvres were acceptable when the difference between the best (largest) 2 FVC values was $\leq 0.15 \mathrm{~L}$ and the difference between the best (largest) FEV1 values was $\leq 0.15 \mathrm{~L}$. For those with an FVC $\leq 1.0 \mathrm{~L}$, the difference for both these measures was within 0.10 L. In PEFR, the highest reading out of 3 acceptable readings was recorded.

Children who were unable to perform the test successfully were excluded from the test. The main reasons for exclusion were shallow or short inhalation, short exhalation, coughing or laughing during the test, inability to seal lips properly around the spirometer, or annoyance due to the nasal clips. In Visit 1, 25 children were excluded from the test and 33 were excluded in Visit 3 when new children were enrolled into the study.

\section{Statistical analysis}

The Global Lung Function Initiative equations (15) were used to calculate predicted values of FEV1 and FVC. The continuous variables of height, age, weight and lung function parameters were expressed as means and standard deviations (SD). The ratio of FEV1/FVC was expressed as a percentage.

Generalized linear mixed models were used to analyse factors associated with pulmonary function test results. The regression was modelled on 3 levels, by clustering by individual, then by location, and by time for repeated measures. As the variance of the pulmonary function measurements changes with height and age (16), pulmonary function measurements were transformed to the natural logarithm to obtain homoscedasticity in relation to height and age (17).

Obesity was evaluated by using the Egyptian BMI growth charts (18). BMI > 95th percentile was used as the cut-off for determining obesity. The model included logarithms 
of height and age, location, sex, breastfeeding, obesity and maternal and paternal atopy (asthma or eczema). Multicollinearity across levels of the model was checked by inspecting variance inflation factors; although logarithms of height and age were significantly correlated, the variance inflation factor was $<3$. Pearson correlations of pulmonary outcomes with every continuous predictor at each time period were performed to estimate linear trends. The normality of the distribution of the outcomes was assessed using plots of outcomes across values of each independent variable and by examining histograms of the residuals.

Factorial repeated measures analysis of variance was used to evaluate the differences in the rate of change in FEV1 pred\%, FVC pred\% and PEFR between Cairo and Shben El-Kom. Statistical tests were carried out using SPSS, version 17.

\section{Ethical consideration}

Ethical approval for the research was obtained from the Research Ethics Committee of the University of Sunderland, and the Egyptian Ministry of Education.

\section{Results}

Table 1 shows the number of children tested in the 5 visits. In the first 2 visits, 109 boys and 85 girls were recruited from Cairo and 127 boys and 85 girls were recruited from Shibin El-Kom. In the last 3 visits (Visits 3, 4 and 5), 204 boys and 169 girls were recruited in Cairo and 209 boys and 151 girls were recruited in Shibin El-Kom. The table shows high numbers of drop-outs in the third visit because all children who had a smoking parent/relative at home or had a pulmonary or heart disease were excluded from the study and new recruits were added to increase the sample size.

The physical measurements of the children were comparable between the 2 locations at all visits and no significant differences were found. Table 2 shows physical measurements in the first and last visits (Visits 1 and 5). The t-test indicated that there were no significant differences between the 2 locations in age, height and BMI for both sexes $(\mathrm{P}>0.05$ for all).

FVC, FEV1, FEV1/FVC\%, FVC predicted\%, FEV1 predicted\% and PEFR were higher in Shibin El-Kom than Cairo among boys and girls in all visits (Table 3)
Scale reliability analyses were performed to examine test-retest reliability for the last 3 visits as these included the largest sample sizes. The results showed high consistency in height and weight (Cronbach alpha $=0.998$ and 0.990 respectively). A repeated measure ANOVA was used to compare the changes in pulmonary function in the last 3 visits between the 2 locations (Table 4).

There were significant differences in the changes between the 2 locations in the last 3 visits in FVC predicted\% $(\mathrm{F}=10.05, \mathrm{P}<0.001), \mathrm{FEV} 1$ predicted\% $(\mathrm{F}=$ 17.68, $P<0.01)$ and PEFR $(\mathrm{F}=7.47, \mathrm{P}<0.01)$ in boys, and FVC predicted\%, $(\mathrm{F}=40.34, \mathrm{P}<0.01), \mathrm{FEV} 1$ predicted\% $(\mathrm{F}$ $=47.69, P<0.01)$ and PEFR $(F=5.01, P=0.03)$ in girls. The changes that occurred in pulmonary function test results between Visit 3 and Visit 5 were calculated to identify the direction of change in pulmonary function between the 2 locations. In boys, between Visit 3 and Visit 5, FVC predicted\% increased by $3.25 \%$ in Cairo versus $11.50 \%$ in Shibin El-Kom; FEV1 predicted\% increased by $1.83 \%$ in Cairo versus $9.20 \%$ in Shben El-Kom; and PEFR increased by $11.20 \mathrm{~L} / \mathrm{min}$ in Cairo versus $18.92 \mathrm{~L} / \mathrm{min}$ in Shben ElKom. In girls, between Visit 3 and Visit 5, FVC predicted\% increased by $4.35 \%$ in Cairo versus $10.33 \%$ in Shibin ElKom, FEV1 predicted\% increased by $2.06 \%$ in Cairo versus 9.68\% in Shibin El-Kom and PEFR increased by $12.89 \mathrm{~L} /$ min in Cairo versus $16.37 \mathrm{~L} / \mathrm{min}$ in Shibin El-Kom.

A generalized linear mixed model was used to analyse factors associated with pulmonary function. Table 5 shows the results for the data gathered from all 5 rounds after excluding the data obtained from children who were exposed to passive smoking or suffered from a respiratory condition who were enrolled in either of the first 2 visits. Risk factors were included in the regression analysis without adjusting for any confounding factors. The analysis included the data collected from 416 children in Visits 1 and 2, and 733 children in the rest of the visits

The analysis indicated that living in Cairo, obesity and maternal atopy (asthma/eczema) had a significant negative association with FVC. Height, age and being male had a significant positive association with FVC. Living in Cairo, obesity and paternal and maternal atopy had a significant negative association with FEV1. Height, age, breastfeeding and being male had a significant positive association with FEV1. Living in Cairo, obesity and maternal atopy had a significant negative association with PEFR, while height and breastfeeding had a

\begin{tabular}{|c|c|c|c|c|c|c|c|c|c|c|c|c|c|c|c|c|}
\hline \multirow[t]{3}{*}{ Visit } & \multicolumn{4}{|c|}{ Remained in } & \multicolumn{4}{|c|}{ Added in } & \multicolumn{4}{|c|}{ Dropped out } & \multicolumn{4}{|c|}{ Total number } \\
\hline & \multicolumn{2}{|c|}{ Cairo } & \multicolumn{2}{|c|}{ Shibin El-Kom } & \multicolumn{2}{|c|}{ Cairo } & \multicolumn{2}{|c|}{ Shibin El-Kom } & \multicolumn{2}{|c|}{ Cairo } & \multicolumn{2}{|c|}{ Shibin El-Kom } & \multicolumn{2}{|c|}{ Cairo } & \multicolumn{2}{|c|}{ Shibin El-Kom } \\
\hline & Boys & Girls & Boys & Girls & Boys & Girls & Boys & Girls & Boys & Girls & Boys & Girls & Boys & Girls & Boys & Girls \\
\hline 1 & - & - & - & - & 109 & 95 & 127 & 85 & - & - & - & - & 109 & 95 & 127 & 85 \\
\hline 2 & 109 & 95 & 127 & 85 & - & - & - & - & - & - & - & - & 109 & 95 & 127 & 85 \\
\hline 3 & 80 & 20 & 35 & 40 & 124 & 149 & 174 & 111 & 29 & 75 & 92 & 45 & 204 & 169 & 209 & 151 \\
\hline 4 & 204 & 169 & 209 & 151 & - & - & - & - & - & - & - & - & 204 & 169 & 209 & 151 \\
\hline 5 & 204 & 169 & 209 & 151 & - & - & - & - & - & - & - & - & 204 & 169 & 209 & 151 \\
\hline
\end{tabular}




\begin{tabular}{|c|c|c|c|c|c|c|c|c|}
\hline \multirow[t]{3}{*}{ Variable } & \multicolumn{4}{|c|}{ Visit 1} & \multicolumn{4}{|c|}{ Visit 5} \\
\hline & \multicolumn{2}{|c|}{ Cairo } & \multicolumn{2}{|c|}{ Shibin El-Kom } & \multicolumn{2}{|c|}{ Cairo } & \multicolumn{2}{|c|}{ Shibin El-Kom } \\
\hline & $\begin{array}{c}\text { Boys } \\
(n=109)\end{array}$ & $\begin{array}{c}\text { Girls } \\
(n=95)\end{array}$ & $\begin{array}{c}\text { Boys } \\
(n=127)\end{array}$ & $\begin{array}{c}\text { Girls } \\
(n=85)\end{array}$ & $\begin{array}{c}\text { Boys } \\
(n=209)\end{array}$ & $\begin{array}{c}\text { Girls } \\
(n=169)\end{array}$ & $\begin{array}{c}\text { Boys } \\
(n=204)\end{array}$ & $\begin{array}{c}\text { Girls } \\
(n=151)\end{array}$ \\
\hline Age (years) & $8.91(0.82)$ & $8.76(0.78)$ & $8.87(1.13)$ & $8.82(1.06)$ & $10.00(1.00)$ & $10.33(0.97)$ & $10.54(1.13)$ & $10.41(1.11)$ \\
\hline Height $(\mathrm{cm})$ & $129.68(8.13)$ & $129.74(7.55)$ & $131.20(8.49)$ & $128.51(7.34)$ & $135.10(8.79)$ & $135.68(7.96)$ & $136.72(8.83)$ & $135.17(7.97)$ \\
\hline Weight (kg) & $30.79(6.90)$ & $30.14(7.12)$ & $29.39(7.11)$ & $28.84(6.16)$ & $34.89(7.08)$ & $35.10(7.72)$ & $35.51(7.28)$ & $34.23(6.84)$ \\
\hline Body mass index $\left(\mathrm{kg} / \mathrm{m}^{2}\right)$ & $17.80(2.80)$ & $18.19(2.88)$ & $17.53(2.59)$ & $17.89(2.82)$ & $19.02(2.97)$ & $18.89(2.90)$ & $18.86(2.67)$ & $18.64(2.76)$ \\
\hline
\end{tabular}

Values are expressed as mean (standard deviation).

significant positive association with PEFR.

\section{Discussion}

The results of the pulmonary function test showed that FVC, FEV1, FEV1/FVC\% and PEFR for boys and girls were higher in Shibin El-Kom compared with Cairo. Living in Cairo decreased FEV1, FVC and PEFR compared with Shibin El-Kom. The Global Lung Function Initiative equations were used to calculate FEV1 predicted and FVC predicted and the results showed that these measures were all higher in Shibin El-Kom than Cairo. These findings confirm previous studies that reported differences in pulmonary function between urban and rural areas $(8,19)$, which could indicate sub-clinical airway narrowing and slower pulmonary growth rate (3).

The decrease in FVC and FEV1 was likely due to decrease in lung tissue elasticity and an increase in big airway resistance, although obstructions in small airways can also decrease FEV1 (20). The decrease in PEFR is an indicator of small and peripheral airway obstruction (4). Air pollution can lead to oxidative stress in the respiratory tract resulting in airway inflammation and injury which leads to a decrease in pulmonary function. The adverse effects of exposure to air pollution will appear in small airways before large ones (4). Thus, the reduction in FVC found in our study in Cairo indicates that the adverse effects of air pollution were long-standing. The differences we observed in lung function between the rural and urban areas as reported by other studies (21) could be attributed to outdoor air pollution (4), indoor air pollution (22), exposure to farm animals (8), farming activities (7), infections, pets, dietary habits, parasitic infections and allergen exposure (3). While we initially intended to consider ambient air pollution as a risk factor, it was difficult to do this in our 2-community design, due to difficulties in measuring personal exposure to outdoor and indoor air pollution, which requires equipment, localized air pollution data, and the time spent outdoors for each child. Gathering this information, if possible, needed funds that were not available for this study.

The results of the generalized linear mixed model indicated that obesity was negatively associated with FVC, FEV1 and PEFR. This supports earlier work with children aged 6-11 years that found that FVC, FEV1, forced expiratory flow $25-27 \%$ and FEV1/FVC were significantly reduced in overweight or obese children compared with those of normal weight (23). The decrease in FVC and FEV1 reported in our study indicates that obesity induces symptoms similar to those seen in restrictive pulmonary disease by adding external load on the chest wall, resistance within the respiratory system, respiratory muscle function, and airway structure or function (24). Obesity may change airway function by increasing bronchial hyper-responsiveness (25). In addition, pulmonary inflammation may be enhanced in obese children because adipose tissue is a source of proinflammatory cytokines and chemokines (25).

The generalized linear mixed model results showed that parental atopy was negatively associated with FVC,

\begin{tabular}{lcccc}
\hline $\begin{array}{l}\text { Table } 3 \text { Lung function measures in Visit } \mathbf{5} \\
\text { Pulmonary test }\end{array}$ & Cairo & & \multicolumn{2}{c}{ Shibin El-Kom } \\
& Boys $(\mathbf{n = 2 0 9 )}$ & Girls $(\mathbf{n}=\mathbf{1 6 9})$ & Boys $(\mathbf{n}=\mathbf{2 0 4})$ & Girls $(\mathbf{n}=151)$ \\
FVC (L) & $2.02(0.48)$ & $1.91(0.42)$ & $2.22(0.47)$ & $2.10(0.40)$ \\
FEV1 (L) & $1.80(0.49)$ & $1.69(0.46)$ & $2.06(0.49)$ & $1.92(0.43)$ \\
FEV/FVC 100 & $88.67(8.73)$ & $88.03(9.92)$ & $92.48(8.72)$ & $91.04(8.13)$ \\
FVC predicted\% & $99.72(10.94)$ & $100.82(10.70)$ & $106.73(9.00)$ & $110.64(9.44)$ \\
FEV1 predicted\% & $101.20(11.41)$ & $99.30(11.24)$ & $109.80(10.90)$ & $111.70(10.52)$ \\
PEFR (L/min) & $202.93(61.52)$ & $201.03(59.51)$ & $222.57(60.03)$ & $218.2(68.64)$ \\
\hline
\end{tabular}

Values are expressed as mean (standard deviation).

$F V C=$ forced vital capacity, $F E V 1=$ forced expiratory volume in the first second, $F E V 1 / F V C^{*} 100=$ forced expiratory rate, $P E F R=$ peak expiratory flow rate. 


\begin{tabular}{|c|c|c|c|c|c|c|}
\hline \multirow[t]{2}{*}{ Measurement } & \multicolumn{3}{|c|}{ Boys } & \multicolumn{3}{|c|}{ Girls } \\
\hline & $\boldsymbol{F}$ & $P$-value & Partial $\eta^{2}$ & $\boldsymbol{F}$ & P-value & Partial $\eta^{2}$ \\
\hline FVC pred\% & 10.05 & $<0.001$ & 0.02 & 40.34 & $<0.01$ & 0.11 \\
\hline FEV1 pred\% & 17.68 & $<0.001$ & 0.04 & 47.69 & $<0.01$ & 0.13 \\
\hline PEFR & 7.47 & 0.01 & 0.02 & 5.01 & 0.03 & 0.02 \\
\hline
\end{tabular}

$F V C=$ forced vital capacity, $F E V 1=$ forced expiratory volume in the first second, PEFR = peak expiratory flow rate.

\begin{tabular}{|c|c|c|c|c|c|c|c|c|c|}
\hline \multirow[t]{2}{*}{ Variable } & \multicolumn{3}{|c|}{ FVC } & \multicolumn{3}{|c|}{ FEV1 } & \multicolumn{3}{|c|}{ PEFR } \\
\hline & Coefficient & P-value & $95 \%$ CI & Coefficient & P-value & $95 \%$ CI & Coefficient & P-value & $95 \%$ CI \\
\hline Intercept & -12.55 & $<0.001$ & -13.41 to -11.68 & -12.8 & $<0.001$ & -13.99 to -11.61 & -3.95 & $<0.001$ & -5.22 to -2.68 \\
\hline Cairo & -0.05 & $<0.001$ & -0.05 to -0.05 & -0.06 & $<0.001$ & -0.06 to -0.06 & -0.07 & $<0.001$ & -0.07 to -0.65 \\
\hline Male & 0.03 & 0.01 & 0.01 to 0.06 & 0.04 & 0.002 & 0.01 to 0.06 & 0.00 & 0.87 & -0.02 to 0.01 \\
\hline Paternal atopy & 0.00 & 0.39 & 0 to 0 & -0.011 & $<0.001$ & -0.02 to -0.01 & 0.00 & 0.91 & -0.03 to 0.03 \\
\hline Maternal atopy & -0.03 & $<0.001$ & -0.04 to -0.03 & -0.032 & $<0.001$ & -0.04 to -0.02 & -0.07 & 0.02 & -0.13 to -0.01 \\
\hline $\begin{array}{l}\text { Breast- } \\
\text { feeding }\end{array}$ & 0.01 & 0.05 & 0 to 0.02 & 0.017 & $<0.001$ & 0.01 to 0.03 & 0.03 & $<0.001$ & 0.03 to 0.03 \\
\hline Obesity & -0.08 & $<0.001$ & -0.09 to -0.07 & -0.09 & $<0.001$ & -0.1 to -0.08 & -0.20 & $<0.001$ & -0.20 to -0.2 \\
\hline Iog(age) & 0.08 & $<0.001$ & 0.08 to 0.09 & 0.08 & $<0.001$ & 0.05 to 0.12 & -0.04 & 0.47 & -0.13 to 0.06 \\
\hline $\operatorname{Iog}(h t)$ & 2.66 & $<0.001$ & 2.48 to 2.84 & 2.69 & $<0.001$ & 2.42 to 2.95 & 1.91 & $<0.001$ & 1.70 to 2.12 \\
\hline
\end{tabular}

Values are expressed as mean (standard deviation).

$F V C=$ forced vital capacity, $F E V 1=$ forced expiratory volume in the first second, $P E F R=$ peak expiratory flow rate. $C I=$ confidence interval

FEV1 and PEFR. This corroborates previous work that found a negative association between parental atopy and pulmonary function in offspring (26). This suggests a genetic effect on bronchial hyper-responsiveness.

The results of the generalized linear mixed model also indicated that breastfeeding was positively associated with FVC, FEV1 and PEFR which supports previous work (27). This beneficial effect could be due to the physical training of prolonged suckling at the breast that induces improvement on the mechanics of ventilation (28) or immunoactive factors present in the breast milk such as cytokines and chemokines which may reduce allergic susceptibility of the lung tissue (29); this interpretation is supported by our finding in our previous report that breastfeeding had a protective effect against wheeze and allergic rhinitis (12).

Significant differences were found in pulmonary function tests for the change rates of FVC predicted\%, FEV1 predicted\% and PEFR in boys and girls between the 2 locations. This corroborates the adverse effects of air pollution on lung function growth found in previous studies as measured by lung function tests (4). The deficit in growth of FVC and FEV1 could be due to the reduction in alveoli growth (29), airway inflammation and diseases (30) or oxidative stress (31).

\section{Limitations of study}

There are several limitations to our study. First, there is no equation to calculate predicted FVC and FEV1 specif- ically formulated for Egyptian children. Predicted FEV1 and FVC are however calculated by height and gender and the generalized linear mixed model used to analyse factors associated with pulmonary function test included these variables. Moreover, the main aim of the pulmonary function test performed in this study was to compare healthy Egyptian children living in rural areas with those living urban areas; it was not used as a diagnostic tool to evaluate a specific individual health condition.

Second, data on some potential risk factors were unavailable, including birth weight, indoor air pollution from fuel used for cooking, socioeconomic status or parents' education. However, to tease out different risk factors, a hierarchical test of 3 levels was performed to estimate the contribution of the clustering variable (i.e. location or person) to the outcome. Furthermore, in Egypt the educational level or occupation of the parent is not an accurate indicator of financial and social status (32).

Third, as the children were given the questionnaire and the consent form to take home to be completed by their parents, any parents who were illiterate and did not have anyone at home to help them complete the questionnaire would not have been able to participate in the study. Given that the schools were considered to have children from middle-class backgrounds, few, if any, parents would have been illiterate.

\section{Conclusion}

Differences in pulmonary function in the 2 locations in- 
creased significantly with time, indicating a negative effect on lung function of living in urban Cairo. This is one of the first longitudinal studies to examine the lung function of Egyptian children and the associated risk factors in urban and rural environments. The findings of this study could be used to help develop policies in Egypt and other developing countries to improve respiratory health of children, including promoting breastfeeding and reducing outdoor air pollution.

Funding: AlZaytoonah University of Jordan.

Competing interests: None declared.

\section{Tests de la fonction pulmonaire chez des écoliers égyptiens en milieu rural et urbain Résumé}

Contexte : Des études précédentes ont montré une association négative entre le milieu urbain et la fonction pulmonaire.

Objectifs : La présente étude longitudinale a examiné l'effet d'un environnement urbain sur les tests de la fonction pulmonaire chez l'enfant en comparant des enfants vivant en milieu urbain et rural en Égypte. L'effet d'autres facteurs sur la fonction pulmonaire, tels que l'obésité, l'allaitement au sein et l'atopie parentale, a également été examiné.

Méthodes : Des enfants d'âge compris entre 7 et 12 ans vivant dans les zones rurales de Shibin El-Kom et dans des zones urbaines du Caire ont été inclus dans cette étude. Le volume maximal expiré pendant la première seconde d'une expiration forcée (VEMS), la capacité vitale forcée (CVF), le débit expiratoire forcé et le débit expiratoire de pointe (DEP) ont été mesurés à cinq reprises sur une période de 2 ans, à intervalles de six mois. L'analyse de variance factorielle à mesures répétées a été utilisée pour évaluer les différences dans le taux de modification pour le pourcentage prévu du VEMS, de la CVF et du DEP entre les enfants du Caire et de Shibin El Kom. Des modèles mixtes linéaires généralisés ont été utilisés pour analyser les facteurs associés aux résultats des tests de la fonction pulmonaire.

Résultats : La régression linéaire généralisée a montré que le fait de vivre au Caire diminuait le log(CVF), le log(VEMS) et le $\log (\mathrm{DEP})$. Des différences significatives ont été constatées dans les changements survenant entre les deux emplacements au cours des trois dernières visites; les enfants du Caire présentant une augmentation plus faible de la fonction pulmonaire.

Conclusions : Les différences au niveau de la fonction pulmonaire dans les deux emplacements augmentaient considérablement avec le temps, ce qui indique un effet négatif de la vie en zone urbaine du Caire sur la fonction pulmonaire. Ces conclusions pourraient être utilisées pour contribuer à l'élaboration de politiques en Égypte et dans d'autres pays en développement pour améliorer la santé respiratoire, y compris la promotion de l'allaitement au sein et la réduction de la pollution de l'air dans les habitations.

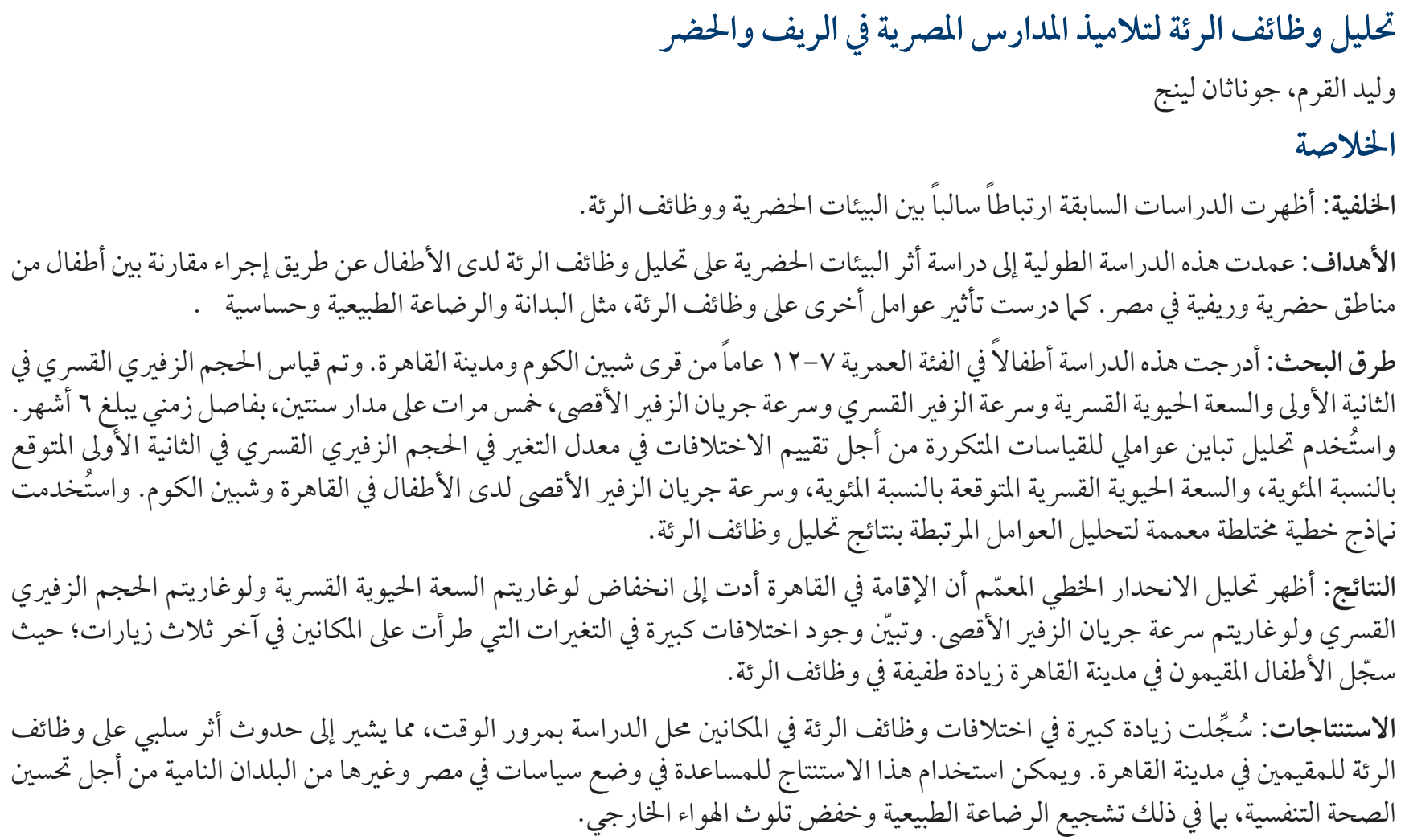




\section{References}

1. World Health Organization. Media centre. Ambient (outdoor) air quality and health. Fact sheet. Updated September 2016. (http:// www.who.int/mediacentre/factsheets/fs313/en/, accessed 7 December 2017)

2. HEI Panel on the Health Effects of Traffic-Related Air Pollution. Traffic-related air pollution: a critical review of the literature on emissions, exposure, and health effects. Special report 17. Boston: Health Effects Institute; 2010.

3. Priftis KN, Mantzouranis EC, Anthracopoulos MB. Asthma symptoms and airway narrowing in children growing up in an urban versus rural environment. J Asthma. 2009 Apr;46(3):244-51. http://dx.doi.org/10.1080/02770900802647516 PMID:19373631

4. He Q-Q, Wong TW, Du L, Jiang Z-Q, Gao Y, Qiu H, et al. Effects of ambient air pollution on lung function growth in Chinese schoolchildren. Respir Med. 2010 Oct;104(10):1512-20. http://dx.doi.org/10.1016/j.rmed.2010.04.016 PMID:20471233

5. Renzetti G, Silvestre G, D’Amario C, Bottini E, Gloria-Bottini F, Bottini N, et al. Less air pollution leads to rapid reduction of airway inflammation and improved airway function in asthmatic children. Pediatrics. 2009 Mar;123(3):1051-8. http://dx.doi. org/10.1542/peds.2008-1153 PMID:19255039

6. Hugg TT, Jaakkola MS, Ruotsalainen R, Pushkarev V, Jaakkola JJK. Exposure to animals and the risk of allergic asthma: a population-based cross-sectional study in Finnish and Russian children. Environ Health. 200806 6;7(1):28. http://dx.doi.org/10.1186/1476069X-7-28 PMID:18538018

7. Ege MJ, Frei R, Bieli C, Schram-Bijkerk D, Waser M, Benz MR, et al.; PARSIFAL Study team. Not all farming environments protect against the development of asthma and wheeze in children. J Allergy Clin Immunol. 2007 May;119(5):1140-7. http://dx.doi. org/10.1016/j.jaci.2007.01.037 PMID:17349684

8. Morcos MM, Morcos WM, Ibrahim MA, Shaheen MA. Environmental exposure to endotoxin in rural and urban Egyptian school children and its relation to asthma and atopy. Minerva Pediatr. 2011 Feb;63(1):19-26. PMID:21311426

9. van der Spoel E, Rozing MP, Houwing-Duistermaat JJ, Slagboom PE, Beekman M, de Craen AJM, et al. Association analysis of insulin-like growth factor-1 axis parameters with survival and functional status in nonagenarians of the Leiden Longevity Study. Aging (Albany NY). 2015 Nov;7(11):956-63. http://dx.doi.org/10.18632/aging.100841 PMID:26568155

10. CIA. The World Factbook. Africa. Egypt (www.cia.gov/library/publications/the-world-factbook/geos/print_eg.html, accessed 23 November 2017).

11. Cohen J. Statistical power analysis for the behavioral sciences. 2nd ed. Mahwah (NJ): Lawrence Earlbaum Associates; 1988.

12. Al-Qerem WA, Ling J, Pullen R, McGarry K. Reported prevalence of allergy and asthma in children from urban and rural Egypt. Air Qual Atmos Heal. 2015 Nov 5;1-8.

13. Asher MI, Strachan DP, Pearce N, García-Marcos L, editors. The ISAAC story The International Study of Asthma and Allergies in Childhood. Auckland: The International Study of Asthma and Allergies in Childhood; 2011.

14. Miller MR, Hankinson J, Brusasco V, Burgos F, Casaburi R, Coates A, et al.; ATS/ERS Task Force. Standardisation of spirometry. Eur Respir J. 2005 Aug;26(2):319-38. http://dx.doi.org/10.1183/09031936.05.00034805 PMID:16055882

15. Quanjer PH, Stanojevic S, Cole TJ, Baur X, Hall GL, Culver BH, et al.; ERS Global Lung Function Initiative. Multi-ethnic reference values for spirometry for the 3-95-yr age range: the global lung function 2012 equations. Eur Respir J. 2012 Dec;40(6):1324-43. http://dx.doi.org/10.1183/09031936.00080312 PMID:22743675

16. Koopman M, Zanen P, Kruitwagen CLJJ, van der Ent CK, Arets HGM. Reference values for paediatric pulmonary function testing: The Utrecht dataset. Respir Med. 2011 Jan 1;105(1):15-23. http://dx.doi.org/10.1016/j.rmed.2010.07.020 PMID:20889322

17. França DC, Camargos PA, Jones MH, Martins JA, Vieira Bda S, Colosimo EA, et al. Prediction equations for spirometry in four- to six-year-old children. J Pediatr (Rio J). 2016;92(4):400-8. http://dx.doi.org/10.1016/j.jped.2015.10.005 PMID:27161560

18. Ghalli I, Salah N, Hussien F, Erfan ME, Mazen M, Sabry I, et al. Egyptian growth curves 2002 for infants, children and adolescents. Reproduced in: Sartorio A, Buckler JMH, Marazzi N, editors. Crescere nel mondo 2008: una raccolta di carte di crescita. Milan: Energy Communications srl; 2008.

19. Robinson CL, Baumann LM, Romero K, Combe JM, Gomez A, Gilman RH, et al. Effect of urbanisation on asthma, allergy and airways inflammation in a developing country setting. Thorax. 2011 Dec;66(12):1051-7. http://dx.doi.org/10.1136/thx.2011.158956 PMID:21730351

20. Liu L, Zhang J. Ambient air pollution and children's lung function in China. Environ Int. 2009 Jan;35(1):178-86. http://dx.doi. org/10.1016/j.envint.2008.06.004 PMID:18789532

21. Asgari MM, DuBois A, Asgari M, Gent J, Beckett WS. Association of ambient air quality with children's lung function in urban and rural Iran. Arch Environ Health. 1998 May-Jun;53(3):222-30. http://dx.doi.org/10.1080/00039899809605699 PMID:9814719

22. Kumar R, Nagar JK, Kumar H, Kushwah AS, Meena M, Kumar P, et al. Indoor air pollution and respiratory function of children in Ashok Vihar, Delhi: an exposure-response study. Asia Pac J Public Health. 2008;20(1):36-48. http://dx.doi. org/10.1177/1010539507308248 PMID:19124297

23. Spathopoulos D, Paraskakis E, Trypsianis G, Tsalkidis A, Arvanitidou V, Emporiadou M, et al. The effect of obesity on pulmonary lung function of school aged children in Greece. Pediatr Pulmonol. 2009 Mar;44(3):273-80. http://dx.doi.org/10.1002/ppul.20995 PMID:19208374

24. Rabec C, de Lucas Ramos P, Veale D. Respiratory complications of obesity. Arch Bronconeumol. 2011 May;47(5):252-61. http://dx. doi.org/10.1016/j.arbres.2011.01.012. PMID:21458904 
25. Shore SA. Obesity, airway hyperresponsiveness, and inflammation. J Appl Physiol (1985). 2010 Mar;108(3):735-43. http://dx.doi. org/10.1152/japplphysiol.00749.2009 PMID:19875711.

26. Christie GL, Helms PJ, Ross SJ, Godden DJ, Friend JA, Legge JS, et al. Outcome of children of parents with atopic asthma and transient childhood wheezy bronchitis. Thorax. 1997 Nov;52(11):953-7. http://dx.doi.org/10.1136/thx.52.11.953 PMID:9487342

27. Guilbert TW, Stern DA, Morgan WJ, Martinez FD, Wright AL. Effect of breastfeeding on lung function in childhood and modulation by maternal asthma and atopy. Am J Respir Crit Care Med. 2007 Nov 1;176(9):843-8. http://dx.doi.org/10.1164/rccm.200610-1507OC PMID:17690333

28. Ogbuanu IU, Karmaus W, Arshad SH, Kurukulaaratchy RJ, Ewart S. Effect of breastfeeding duration on lung function at age 10 years: a prospective birth cohort study. Thorax. 2009 Jan;64(1):62-6. http://dx.doi.org/10.1136/thx.2008.101543 PMID:19001004

29. Kurmi OP, Devereux GS, Smith WCS, Semple S, Steiner MFC, Simkhada P, et al. Reduced lung function due to biomass smoke exposure in young adults in rural Nepal. Eur Respir J. 2013 Jan;41(1):25-30. http://dx.doi.org/10.1183/09031936.00220511 PMID:22556024.

30. Shi W, Bellusci S, Warburton D. Lung development and adult lung diseases. Chest. 2007 Aug;132(2):651-6. http://dx.doi. org/10.1378/chest.06-2663 PMID:17699136

31. Villegas L, Stidham T, Nozik-Grayck E. Oxidative stress and therapeutic development in lung diseases. J Pulm Respir Med. 2014 Aug;4(4). pii:194. http://dx.doi.org/10.4172/2161-105X.1000194 PMID:27019769

32. Assaad R, Krafft C, Roemer J, Salehi-Isfahani D. Inequality of opportunity in wages and consumption in Egypt. Rev Income Wealth. 2017 Mar (Accepted/In press). 